\title{
The impact of debt management on corporate earnings: Indebtedness and its effects on the financial performance of selected Visegrad group enterprises
}

\author{
Katarina Valaskova ${ }^{1, *}$ and Dominika Gajdosikova ${ }^{1}$ \\ ${ }^{1}$ University of Zilina, Faculty of Operation and Economics of Transport and Communications, \\ Univerzitna 1, 01026 Zilina, Slovakia
}

\begin{abstract}
Research background: One of the significant problems of corporate financial management in the international context is the appropriate determination of the total amount of capital as well as the correct composition of financial sources to finance the activities of enterprises. The determination of the optimal capital structure, and thus the minimization of the costs of capital have been of interest to authors worldwide for several decades, as they can significantly influence the level of corporate earnings.

Purpose of the article: The main aim of the paper is to find a mathematical formula to determine whether the indebtedness of an enterprise is related to any financial problems or does not affect the financial performance of an enterprise and thus contributes to the profitability, i.e. if the debt management is performed efficiently.

Methods: To find the mathematical formula, we used the financial data of enterprises operating in the selected Visegrad group and calculated the financial ratios of indebtedness, which were further used in the multiple discriminant analysis. The final discriminant function and calculated centroids allow dividing the enterprises into two different groups, with and without financial problems.

Findings \& Value added: The results of this analysis can be used in the international context to determine the appropriate level of indebtedness also in other countries, not only in the Visegrad group, which may be helpful for corporate financial managers or creditors, because optimal indebtedness helps generate revenues.
\end{abstract}

Keywords: debt management; earnings management; globalization; Visegrad countries

JEL Classification: $G 30 ; G 32 ; F 60$

* Corresponding author: katarina.valaskova@fpedas.uniza.sk 


\section{Introduction}

Ayu et al. (2020) in their study explained that one of the significant roles of corporate financial management is the correct determination of the total required amount of capital as well as the correct composition of the sources of financing. Virglerova et al. (2020) confirmed that financial analysis concerns a specific analysis of data, where the primary sources for the analysis include the financial accounting of the organization. To provide the financial analysis in the best possible way, it must also contain an overview of essential non-financial information and interconnect technical and fundamental analysis. Durana et al. (2021) claimed in their publication that financial analysis helps solve various financial difficulties as well as reveal the strengths and weaknesses of enterprises. It draws attention to the correct determination of factors associated with their intensity and also shapes the financial stability of enterprises. It is also a suitable instrument to predict the financial and economic health of a given company, especially in the context of its debts and earnings.

The financial and economic analyses evaluate the past and current development of the company and try to predict future management and stability from a financial point of view. It provides feedback on whether the financial and economic decisions were correct and brought success, or vice versa, failure arising from unfulfilled expected goals of the company (Lazanyi and Lambovska, 2020). In connection with the existence of every company as well as its ability to survive on the market and achieve successful results, performance is one of the relatively frequently used concepts. According to Svabova et al. (2020), performance aims to use both equity and debt effectively, and thus seeks to achieve maximum growth in the market value of the company over the long-term horizon while also ensuring the creation of profit or forming appropriate conditions for the next generation of profits. Financial ratios represent the shares of relative variables that use two or more figures obtained from the available financial statements. In comparison with the required standard, these ratios can reveal whether the company will experience a financial event. A good set of indicators, if well-chosen and correctly analysed, can provide necessary information about possible financial distress or bankruptcy (Verdet-Pelaez and Sanchez-Loscertables, 2021) and level of corporate earnings (Sosnowski, 2021).

Regular measurement and evaluation of traditional, most commonly used financial indicators (profitability, activity, liquidity, or indebtedness) can give companies a certain competitive advantage. Financial problems never appear at the same time, but at certain stages. i.e. a decrease in the value of profitability or production, an increase in the need for working capital, or a rapid deterioration in the state of the capital structure, or even payment insolvency. These financial difficulties can be identified from the relevant financial statements and, given the unexpected and unfavourable developments of previous periods or changes in financial conditions, they may reflect some key problems (Kliestik et al., 2020a). Indebtedness is the measure, which assesses the level of debt in an enterprise and quantifies its impact on corporate earnings. The level of debt affects both risk and profitability (Kramolis and Dobes, 2020), which underlines its importance in the assessment of corporate performance.

Sadiq et al. (2020), Liem and Hien (2020), Pisar and Mazo (2020), Dvorsky et al. (2020) assert that the indicators of indebtedness are used for capital structure monitoring. According to Al-Delawi and Ramo (2020) and Belas et al. (2020), indebtedness indicators provide information on the financial level and structure of debt and the ability of enterprises to deal with this debt. There are countless different factors associated with indebtedness. Indebtedness usually occurs when economic and business entities cease to own a sufficient amount of their own resources, which they would use to finance and cover their business needs, but need external resources to finance their business and investment activities (Setyoputri and Mardijuwono, 2020). According to Dvorsky et al. (2020), the leverage ratio is one of the best indicators of financial distress, because it takes into account the combination 
of internal and external financial sources and it expresses the amount of assets units financed by one capital unit. The higher the value of the leverage ratio, the higher the corporate profit but also the higher the probability of risk associated with financial problems. The high level of financial leverage causes a lower possibility of corporate debts repayment. Financial difficulties are one of the main threats enterprises have to face, regardless of their size and location (Khoja et al., 2019). That is why the early prediction of financial problems has been popular among researchers and academicians around the world for several decades (e.g. Khuong et al., 2020; Durana et al., 2021).

Thus, the main aim of this paper is to quantify the financial performance of selected Visegrad group enterprises in the context of their indebtedness and to find a mathematical formula (using the method of multivariable discriminant analysis), which may distinguish whether the indebtedness of an enterprise is related to any financial problems or does not affect its financial performance. These results can then be used in the global context to set the appropriate level of indebtedness in order to generate a sufficient level of revenues and perform debt management efficiently.

\section{Data and methods}

For the purposes of processing the debt analysis, the construction sector was chosen from individual sectors of the national economy, which is one of the most important sectors within the secondary sectors. Constructions and buildings constitute a significant portion of gross fixed capital in the overall economy as a result of their completion. The construction industry, as a production sector of the state economy, contributes by its output to the volume of gross domestic product. In the period 2015-2020, debt analysis was performed on a sample of 779 enterprises (data were obtained from the Amadeus database and were adjusted for outliers and non-available data), which could be classified as follows: 496 enterprises from the Slovak Republic and 283 enterprises from the Czech Republic (66 large, 342 medium-sized, and 371 small enterprises). The following indebtedness indicators were monitored in all these enterprises in the analysed 5-year period, Table 1.

Table 1. Indebtedness indicators and their optimal values

\begin{tabular}{|l|c|c|}
\hline Indebtedness ratio & Algorithm & Optimal Value \\
\hline Total indebtedness ratio (TI) & $\begin{array}{c}\text { Current and non-current liabilities } \\
\text { to total assets }\end{array}$ & $\begin{array}{c}30-60 \% \\
70-80 \% \text { in DME }\end{array}$ \\
\hline Self-financing ratio (SF) & Shareholders funds to total assets & $>20-30 \%$ \\
\hline Current indebtedness ratio (CI) & Current liabilities to total assets & - \\
\hline $\begin{array}{l}\text { Non-current indebtedness ratio } \\
\text { (NCI) }\end{array}$ & $\begin{array}{c}\text { Non-current liabilities to total } \\
\text { assets }\end{array}$ & - \\
\hline Credit indebtedness ratio (CrI) & $\begin{array}{c}\text { Bank loans and overdrafts to total } \\
\text { assets }\end{array}$ & $350 \%$ \\
\hline Debt-to-equity ratio (DE) & $\begin{array}{c}\text { Current and non-current liabilities } \\
\text { to shareholders funds }\end{array}$ & - \\
\hline Interest coverage ratio (IC) & $\begin{array}{c}\text { Earnings before interest and taxes } \\
\text { to interests paid }\end{array}$ \\
\hline Interest burden ratio (IB) & $\begin{array}{c}\text { Interests paid to earnings before } \\
\text { interest and taxes }\end{array}$ \\
\hline Debt-to-cash-flow ratio (DCF) & $\begin{array}{c}\text { Current and non-current liabilities } \\
\text { to cash flow }\end{array}$ & $3-4$ years \\
\hline Equity leverage ratio (EL) & Total assets to shareholders funds & max. 4 \\
\hline $\begin{array}{l}\text { Financial independence ratio } \\
\text { (FI) }\end{array}$ & $\begin{array}{c}\text { Shareholders funds to current and } \\
\text { non-current liabilities }\end{array}$ & $>3$ \\
\hline
\end{tabular}




\begin{tabular}{|l|c|c|}
\hline Indebtedness ratio & Algorithm & Optimal Value \\
\hline $\begin{array}{l}\text { Non-current assets coverage } \\
\text { ratio (NCAC) }\end{array}$ & $\begin{array}{c}\text { Shareholders fund and non- } \\
\text { current liabilities to non-current } \\
\text { assets }\end{array}$ & $\begin{array}{c}>1 \text { overcapitalization } \\
<1 \text { undercapitalization }\end{array}$ \\
\hline Insolvency ratio (Ins) & $\begin{array}{c}\text { Current and non-current liabilities } \\
\text { to receivables }\end{array}$ & $\begin{array}{c}>1 \text { primary insolvency } \\
<1 \text { secondary insolvency }\end{array}$ \\
\hline
\end{tabular}

Note: DME developed market economies

Source: Bartosova et al. (2020), Kravcakova Vozarova et al. (2019)

The resulting average values of the given indebtedness indicators of enterprises in the construction sector within the Slovak Republic and the Czech Republic for the entire analyzed period are shown in Table 2. All indicators are expressed as coefficients. A comparison of the results revealed significant differences in the financial structure between companies in the construction sector.

Table 2. Average values of the analysed indebtedness ratios

\begin{tabular}{|l|c|c|}
\hline \multirow{2}{*}{\multicolumn{1}{|c|}{ Indebtedness ratio }} & \multicolumn{2}{c|}{ 5-year average values } \\
\cline { 2 - 3 } & SK & CZ \\
\hline Total indebtedness ratio (TI) & 0.735 & 0.566 \\
\hline Self-financing ratio (SF) & 0.273 & 0.434 \\
\hline Current indebtedness ratio (CI) & 0.505 & 0.440 \\
\hline Non-current indebtedness ratio (NCI) & 0.222 & 0.126 \\
\hline Credit indebtedness ratio (CrI) & 0.140 & 0.041 \\
\hline Debt-to-equity ratio (DE) & 2.740 & 1.304 \\
\hline Interest coverage ratio (IC) & 4.338 & 10.380 \\
\hline Interest burden ratio (IB) & 0.189 & 0.106 \\
\hline Debt-to-cash-flow ratio (DCF) & 11.304 & 11.952 \\
\hline Equity leverage ratio (EL) & 3.740 & 2.302 \\
\hline Financial independence ratio (FI) & 0.379 & 0.768 \\
\hline Non-current assets coverage ratio (NCAC) & 1.724 & 2.198 \\
\hline Insolvency ratio (Ins) & 1.284 & 0.862 \\
\hline
\end{tabular}

Source: own calculations

Subsequently, we used the method of multidimensional discriminant analysis (MDA). The explained variable $(\mathrm{Y})$ is the financial prosperity of an enterprise. The explanatory variables $(\mathrm{X})$ consist of individual indebtedness indicators and 2 qualitative variables (company size and legal form), which were added to the model in the form of dummy variables (Csabay and Stehlikova, 2020). In order to form a discriminatory model, it was necessary to divide the individual companies in the sector into two relevant groups. The first group consisted of enterprises with optimal indebtedness without significant financial difficulties, and the second group included enterprises with a higher level of indebtedness even with significant financial difficulties. To form the model, the statute of the company in crisis was used, which suggests that if an enterprise is in a crisis, then the equity-to-debt ratio is less than 0.08 (Kliestik et al., 2020b; Kovacova, et al., 2019).

If the equity-to-debt ratio is below this limit, the company is in crisis, which means that the level of indebtedness in the company is not optimal and the company is experiencing financial distress. If this ratio is higher than the limit, the company is optimally indebted and 
without serious financial difficulties. All calculations were performed using SPSS statistical software.

\section{Results and discussion}

To construct the model, based on the multivariate discriminant analysis (MDA), which should be used to find the appropriate level of corporate indebtedness, several assumptions need to be verified (the significance level was set at 5 per cent). All considered indebtedness ratios were used as input variables of the MDA and their mean values were analysed to prove if these ratios could be used as relevant determinants of optimal indebtedness.

Table 3 summarizes the results of the tests of equity of group means at the $5 \%$ significance level. It is evident that those indebtedness ratios are not appropriate determinants whose sig. value exceeds the significance level, i.e. interest burden ratio, interest coverage ratio and noncurrent assets coverage ratio. Thus, it was proved, that they do not sufficiently differentiate a group of enterprises with and without financial difficulties in the context of indebtedness. Therefore it is necessary to consider their omission and further use in the model. However, those indebtedness ratios with a sig. value below the significance level (marked in bold), were verified as relevant predictors of indebtedness with/without financial difficulties.

Table 3. Test of equity of group means

\begin{tabular}{|l|c|c|c|c|c|}
\hline Indicator & $\begin{array}{c}\text { Wilks' } \\
\text { Lambda }\end{array}$ & F & df1 & df2 & Sig. \\
\hline TI & 0.685 & 358.127 & 1 & 777 & $\mathbf{0 . 0 0 0}$ \\
\hline SF & 0.684 & 358.776 & 1 & 777 & $\mathbf{0 . 0 0 0}$ \\
\hline CI & 0.872 & 114.376 & 1 & 777 & $\mathbf{0 . 0 0 0}$ \\
\hline NCI & 0.901 & 85.338 & 1 & 777 & $\mathbf{0 . 0 0 0}$ \\
\hline CrI & 0.983 & 13.373 & 1 & 777 & $\mathbf{0 . 0 0 0}$ \\
\hline DE & 0.984 & 12.722 & 1 & 777 & $\mathbf{0 . 0 0 0}$ \\
\hline IB & 0.996 & 2.831 & 1 & 777 & 0.093 \\
\hline IC & 1.000 & 0.182 & 1 & 777 & 0.670 \\
\hline FI & 0.947 & 43.859 & 1 & 777 & $\mathbf{0 . 0 0 0}$ \\
\hline NCAC & 0.996 & 2.926 & 1 & 777 & 0.088 \\
\hline DCF & 0.995 & 4.292 & 1 & 777 & $\mathbf{0 . 0 3 9}$ \\
\hline EL & 0.984 & 12.722 & 1 & 777 & $\mathbf{0 . 0 0 0}$ \\
\hline Ins & 0.978 & 17.345 & 1 & 777 & $\mathbf{0 . 0 0 0}$ \\
\hline $\begin{array}{l}\text { Legal form }=\text { limited liability } \\
\text { company (LLC) }\end{array}$ & 0.994 & 4.998 & 1 & 777 & $\mathbf{0 . 0 2 6}$ \\
\hline Size =Medium sized & 0.991 & 6.689 & 1 & 777 & $\mathbf{0 . 0 1 0}$ \\
\hline Size = Small & 0.980 & 15.983 & 1 & 777 & $\mathbf{0 . 0 0 0}$ \\
\hline
\end{tabular}

Source: own calculations

Then it was necessary to verify if the covariance matrices of the groups were identical (Table 4). The results prove that the covariance matrices of the groups are not identical (Table $5)$, as the sig. value is below the significance level. Therefore, the assumption of different covariance matrices was used in the SPSS calculations. The log determinants of the covariance matrices of the individual groups are distant. 
Table 4. Box's test of equity of covariance matrices (log determinants)

\begin{tabular}{|l|c|c|}
\hline & Rank & Log Determinant \\
\hline Indebted with difficulties & 13 & 32.746 \\
\hline Indebted without difficulties & 13 & 32.996 \\
\hline Pooled within-groups & 13 & 43.293 \\
\hline $\begin{array}{l}\text { The ranks and natural logarithms of determinants printed are those of the group covariance } \\
\text { matrices. }\end{array}$ \\
\hline
\end{tabular}

Source: own calculations

Table 5. Box's tests of equity of covariance matrices (test results)

\begin{tabular}{|c|c|r|}
\hline \multicolumn{2}{|c|}{ Box's M } & $8,029.748$ \\
\hline & Approx. & 84.715 \\
\cline { 2 - 3 } F & Df1 & 91 \\
\cline { 2 - 3 } & Df2 & $139,251.158$ \\
\cline { 2 - 3 } & Sig. & 0.000 \\
\hline \multicolumn{2}{|c|}{} \\
\cline { 2 - 3 } & \multicolumn{2}{|c|}{} \\
\hline
\end{tabular}

Source: own calculations

Analysing the summary of the canonical discriminant function (Table 6), two important notes may be revealed: i) if the canonical discriminant function is statistically significant (pvalue of Wilks' Lambda), and ii) how strong is the canonical correlation. The p-value of the Wilks' Lambda (0.000) indicates, that the canonical discriminant function is statistically significant and the canonical correlation is considered medium strong (0.608).

Table 6. Summary of canonical discriminant function

\begin{tabular}{|c|c|c|c|c|}
\hline \multicolumn{5}{|c|}{ Eigenvalues } \\
\hline Function & Eigenvalue & $\%$ of Variance & Cumulative \% & $\begin{array}{c}\text { Canonical } \\
\text { Correlation }\end{array}$ \\
\hline 1 & $0.588^{\text {a }}$ & 100.0 & 100.0 & 0.608 \\
\hline \multicolumn{5}{|c|}{ Wilk's Lambda } \\
\hline $\begin{array}{c}\text { Test of } \\
\text { Function(s) }\end{array}$ & Wilk's Lambda & Chi-square & df & Sig. \\
\hline 1 & 0.630 & 356.109 & 13 & 0.000 \\
\hline
\end{tabular}

Source: own calculations

An important role in the process of model formation is played by the standardized canonical discriminant function coefficients. It must be found, which of the given variables are suitable discriminators between two groups of enterprises, with or without financial difficulties in the context of their indebtedness.

The variables have quite various coefficients, which differ significantly from each other. The best variable with a value of 1.435 can be considered the total indebtedness ratio (TI), which has the greatest strength and the best discriminatory ability. A slightly worse discriminator is the variable size $=$ Small with a value of 0.343 and the third most important is the variable size $=$ Medium sized with a value of 0.167 (Table 7). These results declare the importance of firm size in the process of the debt financing (Duft and Durana, 2020; Keane et al., 2020; Kliestik et al., 2020c) as well as of debt-to-assets ratio (Connolly-Barker et al., 2020; Gray-Hawkins and Lazaroiu, 2020; Nica et al., 2020; or Watson et al., 2020). 
Table 7. Standardized canonical discriminant function coefficients

\begin{tabular}{|l|c|}
\hline \multirow{2}{*}{ Indebtedness ratio } & Function \\
\cline { 2 - 3 } CZ & $\mathbf{1}$ \\
\hline KZ & 1.435 \\
\hline ÚVZ & -0.571 \\
\hline MZVK & -0.110 \\
\hline ÚZ & 0.132 \\
\hline ÚK & 0.017 \\
\hline UFS & 0.029 \\
\hline UKP & 0.160 \\
\hline TZ & -0.044 \\
\hline PN & 0.077 \\
\hline Legal form = LLC & 0.031 \\
\hline Size = Medium sized & -0.011 \\
\hline Size $=$ Small & 0.167 \\
\hline
\end{tabular}

Source: own calculations

The following Table 8 shows the values of the correlation coefficients between the discrimination function and the individual explanatory variables, which are used to assess which of the variables have the greatest discriminatory ability.

The correlation between the total indebtedness ratio and the discrimination function is the strongest, so this variable is also the best discriminator. Other important variables include e.g. current indebtedness ratio, insolvency ratio, financial independence ratio and credit indebtedness ratio. Other variables such as self-financing ratio, financial independence ratio, and size $=$ Medium-sized show only weak dependence, therefore, these variables do not have sufficient influence.

Table 8. Structure matrix

\begin{tabular}{|l|c|}
\hline \multirow{2}{*}{ Indebtedness ratio } & Function \\
\cline { 2 - 3 } & $\mathbf{1}$ \\
\hline $\mathrm{SF}^{\mathrm{a}}$ & -0.887 \\
\hline $\mathrm{TI}$ & 0.886 \\
\hline $\mathrm{CI}$ & 0.501 \\
\hline $\mathrm{NCI}^{\mathrm{a}}$ & 0.432 \\
\hline $\mathrm{FI}$ & -0.310 \\
\hline Ins & 0.195 \\
\hline Size $=$ Small & 0.187 \\
\hline $\mathrm{CrI}$ & 0.171 \\
\hline $\mathrm{DE}$ & 0.167 \\
\hline FPa & 0.167 \\
\hline Size $=$ Medium sized & -0.121 \\
\hline Legal form $=$ LLC & 0.105 \\
\hline
\end{tabular}




\begin{tabular}{|l|c|}
\hline \multirow{2}{*}{ Indebtedness ratio } & Function \\
\cline { 2 - 3 } & $\mathbf{1}$ \\
\hline DCF & 0.097 \\
\hline NCAC & -0.080 \\
\hline IB & 0.079 \\
\hline IC & -0.020 \\
\hline a. This variable not used in the analysis. \\
\hline
\end{tabular}

Source: own calculations

Using non-standardized coefficients of the canonical discriminant function, it is then possible to form a model, based on which, the value of the discriminant score for each company can be calculated:

$$
\begin{aligned}
Z_{S C O R E}=-2,997 & +5,033 \cdot T I-1,738 \cdot C I-0,629 \cdot C r I+0,04 . D E \\
& +0,008 \cdot I B+0,00000006 \cdot I C+0,089 \cdot F I \\
& -0,001 \cdot N C A C+0,000345 \cdot D C F+0,002 . I n s \\
& -0,035 \cdot . L C C+0,337 \cdot \text { mediumsized enterprise } \\
& +0,693 . \text { small enterprise }
\end{aligned}
$$

The given equation predicts by means of a Z-score, which is the status of an enterprise in the context of the indebtedness level, where:

TI - Total indebtedness ratio

$\mathrm{CI}$ - Current indebtedness ratio

$\mathrm{CrI}-$ Credit indebtedness ratio

DE - Debt-to-equity ratio

IB - Interest burden ratio

IC - Interest coverage ratio

FI - Financial independence ratio

$\mathrm{NCAC}-$ Non-current assets coverage ratio

Ins - Insolvency ratio

Because the resulting discriminant model includes a constant, the Z-score must be compared with zero to classify an enterprise into one of two considered groups - indebted

\begin{tabular}{|c|c|c|c|c|c|}
\hline & & \multicolumn{2}{|c|}{ Predicted Group Membership } & \multirow[b]{2}{*}{ Total } \\
\hline & & & $\begin{array}{l}\text { Indebted } \\
\text { with } \\
\text { difficulties }\end{array}$ & $\begin{array}{c}\text { Indebted } \\
\text { without } \\
\text { difficulties }\end{array}$ & \\
\hline \multirow{4}{*}{ Original } & \multirow{2}{*}{ Count } & Indebted with difficulties & 96 & 22 & 118 \\
\hline & & Indebted without difficulties & 44 & 617 & 661 \\
\hline & \multirow{2}{*}{$\%$} & Indebted with difficulties & 81.4 & 18.6 & 100.0 \\
\hline & & Indebted without difficulties & 6.7 & 93.3 & 100.0 \\
\hline
\end{tabular}
enterprise with difficulties and indebted enterprise without difficulties. If the Z-score is less than zero, then the analysed enterprise belongs to a group of enterprises which are indebted but do not have any financial difficulties (the level of indebtedness is optimal).

Table 9. Classification ability of the indebtedness model

Source: own calculations

If the Z-score is greater than zero, then an enterprise belongs to the group of enterprises where the level of indebtedness causes financial problems. To verify the classification ability 
of the model, the results are summarized in the classification table (Table 9), which reveals that the model correctly categorizes $91.5 \%$ of all enterprises. The model classifies $93.3 \%$ of enterprises that are financially sound with their level of indebtedness, and $81.4 \%$ of enterprises are in financial distress caused by their inappropriate level of indebtedness.

\section{Conclusions}

It can be said that the perspectives of Slovak and Czech companies in the construction sector in the selection of capital structures can be considered relatively identical given that the situation and performance of these economies are at a comparative level. Analysed companies operating in the construction sector achieve a positive outcome in the form of profit in the given 5-year period, and generate revenues from operating activities, thus, the indebtedness level can be perceived as optimal. This fact was also confirmed by the results obtained from the discriminant analysis, where 661 out of 779 Slovak and Czech enterprises did not have any problems with financing their debts, while the model identified and 118 companies that were in financial distress due to an inappropriate level of indebtedness.

However, in the coming period, the performance of these companies as well as of the economy can be expected to stagnate and be largely influenced mainly by external factors, especially by the economic consequences of the coronavirus pandemic (e.g. Mitchell et al., 2021; Bailey et al., 2021). For enterprises operating in the construction sector, the effects of the pandemic could cause a significant decline in their construction output related to macroeconomic development, and more expensive financing, and the risks posed by the global economy.

The study has its limitations, which can be perceived in the context of future research challenges. First of all, the research of the central European countries can bring more relevant results as well as the orientation on more sectors. The multi-sectoral analysis can reveal the hidden consequences of the COVID-19 pandemic and find the factors and determinants that influence corporate indebtedness and the overall financial performance of enterprises in the global context.

\section{Acknowledgements}

This research was financially supported by the Slovak Research and Development AgencyGrant NO. APVV-17-0546: Variant Comprehensive Model of Earnings Management in Conditions of the Slovak Republic as an Essential Instrument of Market Uncertainty Reduction, and the science project VEGA 1/0210/19 Research of innovative attributes of quantitative and qualitative fundaments of the opportunistic earnings model.

\section{References}

1. Al-Delawi, A. S., \& Ramo, W. M. (2020). The impact of accounting information system on performance management. Polish Journal of Management Studies, 21(2), 36-48.

2. Ayu, M., Gamayuni, R. R., \& Urbanski, M. (2020). The impact of environmental and social costs disclosure on financial performance mediating by earning management. Polish Journal of Management Studies, 21(1), 74-86.

3. Bailey, L., Grupac, M., and Sosedova, J. (2021). COVID-19 Vaccine Risk Beliefs, Perceptions, Attitudes, and Intentions. Review of Contemporary Philosophy, 20, 81-92

4. Bartosova, V., Paliderova, M., Jaros, J., \& Kovalova, E. (2020). Financial reporting and analysis. Žilina: EDIS. 
5. Belas, J., Amoah, J., Petrakova, Z., Kliuchnikava, Y., Bilan, Y. (2020). Selected Factors of SMEs Management in the Service Sector. Journal of Tourism and Services, 21(11), 129-146.

6. Connolly-Barker, M., Gregova, E., Dengov, V. V., \& Podhorska, I. (2020). Internet of Things Sensing Networks, Deep Learningenabled Smart Process Planning, and Big Data-driven Innovation in Cyber-Physical System-based Manufacturing. Economics, Management and Financial Markets, 15(2), 23-29.

7. Csabay, M., \& Stehlikova, B. (2020). Firm Size Distribution and the Effects of Ownership Type. Journal of Competitiveness, 12(4), 22-38.

8. Duft, G., \& Durana, P. (2020). Artificial intelligence-based decision-making algorithms, automated production systems, and big data-driven innovation in sustainable industry 4.0. Economics, Management and Financial Markets, 15(4), 9-18.

9. Durana, P., Ginevicius, R., Urbanski, M., Podhorska, I., \& Tumpach, M. (2021). Parallels and Differences in Earnings Management of the Visegrad Four and the Baltics. Journal of Competitiveness, 13(3), 39-55.

10. Durana, P., Michalkova, L., Privara, A., Marousek, J., \& Tumpach, M. (2021). Does the life cycle affect earnings management and bankruptcy?. Oeconomia Copernicana, 12(2), 425-461.

11. Dvorsky, J., Petrakova, Z., Ajaz Khan, K., Formanek, I., \& Mikolas, Z. (2020). Selected Aspects of Strategic Management in the Service Sector. Journal of Tourism and Services, 20(11), 109-123.

12. Dvorsky, J., Petrakova, Z., Fialova, V. (2020). Perception of Business Risks by Entrepreneurs According to Experience with the Business Failure. International Journal of Entrepreneurial Knowledge, 8(1), 76-88.

13. Gray-Hawkins, M., \& Lazaroiu, G. (2020). Industrial artificial intelligence, sustainable product lifecycle management, and internet of things sensing networks in cyber-physical smart manufacturing systems. Journal of Self-Governance and Management Economics, 8(4), 19-28.

14. Keane, E., Zvarikova, K., \& Rowland, Z. (2020). Cognitive automation, big data-driven manufacturing, and sustainable industrial value creation in Internet of Things-based realtime production logistics. Economics, Management and Financial Markets, 15(4), 3948.

15. Khoja, L., Chipulu, M., \& Jayasekera, R. (2019). Analysis of financial distress cross countries: using macroeconomic, industrial indicators and accounting data. International Review of Financial Analysis, 66, 1-37.

16. Khuong, N. V., Liem, N. T., \& Minh, M. T. H. (2020). Earnings management and cash holdings: Evidence from energy firms in Vietnam. Journal of international studies, 13(1), 247-261.

17. Kliestik, T., Valaskova, K., Nica, E., Kovacova, M., \& Lazaroiu, G. (2020a). Advanced methods of earnings management: Monotonic trends and change-points under spotlight in the Visegrad countries. Oeconomia Copernicana, 11(2), 371-400.

18. Kliestik, T., Valaskova, K., Lazaroiu, G., Kovacova, M., \& Vrbka, J. (2020b). Remaining financially healthy and competitive: The role of financial predictors. Journal of Competitiveness, 12(1), 74-92.

19. Kliestik, T., Nica, E., Musa, H., Poliak, M., \& Mihai, E. A. (2020c). Networked, smart, and responsive devices in industry 4.0 manufacturing systems. Economics, Management and Financial Markets, 15(3), 23-29. 
20. Kovacova, M., Kliestik, T., Valaskova, K., Durana, P., \& Juhaszova, Z. (2019). Systematic review of variables applied in bankruptcy prediction models of Visegrad group countries. Oeconomia Copernicana, 10(4), 743-772.

21. Kramolis, J., \& Dobes, K. (2020). Debt as a financial risk factor in SMEs in the Czech Republic. Equilibrium-Quarterly Journal of Economics and Economic Policy, 15(1), 87105.

22. Kravcakova Vozarova, I., Kotulic, R., \& Vavrek, R. (2019). Disparities in the financial performance of agricultural entities according to the legal form: the case of Slovakia. Applied Economics, 51(56), 5999-6008.

23. Lazanyi, K., \& Lambovska, M. (2020). Readiness for Industry 4.0 Related Changes: A Case Study of the Visegrad Four. Ekonomicko-manazerske spektrum, 14(2), 100-113.

24. Liem, V. T., \& Hien, N. N. (2020). The impact of manager's demographic characteristics on prospector strategy, use of management accounting systems and financial performance. Journal of International Studies, 13(4), 54-69.

25. Mitchell, K., Grupac, M., and Zauskova, A. (2021). Ethical Management and Implementation of COVID-19 Immunity Passports and Vaccination Certificates: Lawfulness, Fairness, and Transparency. Linguistic and Philosophical Investigations, $20,45-54$.

26. Nica, E., Janoskova, K., \& Kovacova, M. (2020). Smart connected sensors, industrial big data, and real-time process monitoring in cyber-physical system-based manufacturing. Journal of Self-Governance and Management Economics, 8(4), 29-38.

27. Pisar, P. (2020). Controlling, communication and corporate culture-the opportunities for Smes. Economics \& Sociology, 13(3), 113-132.

28. Setyoputri, L. S., \& Mardijuwono, A. W. (2020). The impact of firm attributes on earnings management. Polish Journal of Management Studies, 22(1), 502-512.

29. Sadiq, M., Pantamee, A. A., Mohamad, S., Aldeehani, T. M., \& Ady, S. U. (2020). Corporate governance and earnings management: evidence from listed non-financial firms. Polish Journal of Management Studies, 22(2), 456-469.

30. Sosnowski, T. (2021). The credibility of earnings announced by new stock companies: accrual and real earnings management. Equilibrium-Quarterly Journal of Economics and Economic Policy, 16(3), 661-677.

31. Svabova, L., Kramarova, K., Chutka, J., \& Strakova, L. (2020). Detecting earnings manipulation and fraudulent financial reporting in Slovakia. Oeconomia Copernicana, 11(3), 485-508.

32. Verdet-Pelaez, A., \& Sanchez-Loscertables, P. (2021). Key ratios for long-term prediction of hotel financial distress and corporate default: survival analysis for an economic stagnation. Sustainability, 13(3), 1473.

33. Virglerova, Z., Conte, F., Amoah, J., \& Massaro, M. R. (2020). The Perception of Legal Risk and Its Impact on the Business of SMEs. International Journal of Entrepreneurial Knowledge, 8(2), 1-13.

34. Watson, A., Musova, Z., Machova, V., \& Rowland, Z. (2020). Internet of things-enabled smart cities: big data-driven decision-making processes in the knowledge-based urban economy. Geopolitics, History and International Relations, 12(1), 94-100. 